\title{
Peningkatan Kapasitas Istri Nelayan dalam Pengolahan Hasil Perikanan di Dusun Kuwaru Desa Poncosari, Kecamatan Srandakan, Kabupaten Bantul
}

\section{Capacity Building of Fisherman's Wife in the Processing of Fishery Product in Kuwaru, Poncosari Village, Srandakan, Bantul Regency}

\author{
${ }^{1}$ Agustina Setyaningrum, ${ }^{1 B}$ Broto Widya Hartanto \\ ${ }^{1}$ Program Studi Teknik Kelautan, Fakultas Teknologi Sumber Daya Alam, Institut Teknologi \\ Yogyakarta \\ 2 Program Studi Teknik Industri, Fakultas Teknik Industri, Institut Teknologi Yogyakarta
}

Korespondensi: A. Setyaningrum, agustina678@ity.ac.id

Naskah Diterima: 24 September 2019. Disetujui: 10 Februari 2020. Disetujui Publikasi: 5 Maret 2020

\begin{abstract}
Wife has an important role in helping the family economy. Dusun Kuwaru in Poncosari Village, Bantul Regency is one of Dusun that has a fishing community. During the fishing season many fish catches but some fish are unsold for sale. Fishermen's wife has the opportunities in processing fishery products. However, there are several problem related to this opportunity, namely institutional problem, weak capacity in the processing of fishery product and the difficulty of raw materials during the high wave season. This community partnership program is expected to increase empowerment and increase the capacity of fisherman wife in processing fishery products. The Participatory Rural Appraisal (PRA) approach was used in this activity. With this approach the community has a large role in implementing it. The steps are forming a business group, FGD on mapping the potential of fishery product, socialization of entrepreneuship and business licensing, training of fishery products and training on packaging and marketing. Increasing the capacity of fishermens's wife can be seen through the formation of fish processing groups with their organizational structure, the realization of processed fish products and the realization of more attractive packaging. Processing of fishery products is able to increase the added value of fish and has the potential to become a superior fish product in Yogyakarta.
\end{abstract}

Keywords: Fishermen's wife, capacity, fishing product

\begin{abstract}
Abstrak. Istri memiliki peran yang penting dalam membantu perekonomian keluarga. Dusun Kuwaru di Desa Poncosari, Srandakan Kabupaten Bantul merupakan salah satu dusun yang memiliki masyarakat yang bermata pencaharian sebagai nelayan. Pada saat musim melaut hasil tangkapan ikan sangat banyak, dan terkadang beberapa jenis ikan kurang laku dijual. Istri nelayan dapat mengambil peluang dalam pemanfaatan hasil perikanan melalui pengolahan hasil perikanan. Mekipun demikian, terdapat beberapa permasalahan terkait dengan peluang ini yaitu permasalahan kelembagaan, lemahnya kapasitas dalam usaha pengolahan hasil perikanan dan sulitnya bahan baku saat musim gelombang tinggi. Tujuan dari kegiatan pengabdian ini adalah untuk meningkatkan keberdayaan dan meningkatkan kapasitas istri nelayan dalam pengolahan hasil perikanan. Pendekatan Participatory Rural Appraisal (PRA) digunakan dalam kegiatan ini. Dengan pendekatan ini masyarakat memiliki peran yang besar dalam pelaksanaanya. Tahapan yang dilakukan adalah pembentukan kelompok usaha bersama, FGD pemetaan potensi dan rantai produksi hasil perikanan, Sosialisasi peningkatan jiwa kewirausahaan dan perizinan usaha, Pelatihan hasil perikanan dan Pelatihan pengemasan dan pemasaran. Peningkatan keberdayaan dan kapasitas istri nelayan dapat dilihat melalui
\end{abstract}


terbentuknya kelompok istri nelayan bersama dengan struktur organisasinya, peningkatan jiwa kewirausahan dan pemahaman terkait dengan perizinan, terwujudnya produk olahan ikan serta terwujudnya labeling kemasan yang lebih menarik. Produk olahan ikan dengan menggunakan jenis ikan yang kurang laku mampu meningkatkan nilai tambah ikan dan berpotensi menjadi produk olahan ikan unggulan di DIY.

Kata Kunci: Istri nelayan, kapasitas, hasil perikanan

\section{Pendahuluan}

Dusun Kuwaru yang terletak di Desa Poncosari Kecamatan Srandakan Kabupaten Bantul, memiliki kurang lebih 70 nelayan yang menggantungkan hidupnya pada perikanan tangkap dan budidaya disana. Kondisi nelayan sangat tergantung pada tinggi gelombang Pantai Selatan Daerah IstimewaYogyakarta (DIY). Pada saat musim gelombang tinggi banyak nelayan tidak melaut. Namun pada saat musim melaut terkadang banyak hasil tangkapan ikan yang kurang laku dijual. Ikan yang kurang laku dijual ini terkadang dijadikan pakan lele, kripik ikan atau bahkan dibuang. Istri nelayan dapat mengambil peluang dalam pemanfaatan dan pengolahan hasil perikanan. Hal ini tidak terlepas dari anggapan yang menyebutkan bahwa perempuan memiliki kemampuan dan etos kerja yang tinggi (Sumrin dkk., 2015). Beberapa kajian terkait dengan peran istri nelayan dalam membantu perekonomian keluarga menyebutkan bahwa, istri nelayan dalam usia produktif dan berkerja mampu membantu meningkatkan pendapatan keluarga (Kurniawati, 2017). Pemberdayaan dan peningkatan kapasitas istri nelayan dalam pengolahan hasil perikanan diharapkan mampu meningkatkan partisipasi mereka dalam peningkatan ekonomi keluarga. Peningkatan partisipasi istri nelayan ini akan mendorong terwujudnya kesetaraan gender dan inklusi sosial (Gender Equality and Social Inclusion/GESI).

Kondisi istri nelayan di Dusun Kuwaru sangat beragam. Diantara mereka ada yang sudah berkerja tetapi banyak juga yang hanya menjadi ibu rumah tangga. Sebelumnya ada yang pernah tergabung dalam sebuah Kelompok Usaha Bersama (KUB) pengolahan hasil perikanan. Anggotanya tidak hanya istri nelayan tetapi juga masyarakat umum lainnya di dusun tersebut. KUB ini hanya berjalan hampir dua tahun dan selanjutnya bubar atau tidak berkelanjutan ketika program dari pemerintah dihentikan, KUB ini tidak beraktifitas dan pada akhirnya manajemen usahanya dibubarkan. Mereka ingin kembali membentuk kelompok usaha pengolahan ikan karena pada saat musim melaut banyak hasil tangkapan ikan nelayan yang tidak terjual dan terkadang harus dibuang karena tidak ada yang mengolah.

Beberapa permasalahan yang muncul antara lain permasalahan kelembagaan, lemahnya kapasitas dalam usaha pengolahan hasil perikanan dan sulitnya bahan baku saat musim gelombang tinggi. Permasalahan ini merupakan cerminan dari permasalahan yang dihadapi oleh kelompok usaha yang sebelumnya yang sekarang sudah dibubarkan. Berdasarkan diskusi bersama dengan mitra permasalahan kelembagaan menjadi permasalahan prioritas. Mengaca pada kelompok sebelumnya jumlah anggota dalam kelompok sebelumnya yang sangat banyak dan terdapat anggota yang menjadi pedagang/petani sehingga mereka tidak fokus serta sistem pembagian tugas dalam kelompok yang kurang jelas. Akhirnya banyak anggota yang sering tidak hadir dalam pertemuan, dan juga tidak dapat menjalankan tugasnya dengan baik.

Prioritas permasalahan kedua adalah lemahnya kapasitas dalam usaha pengolahan hasil perikanan. Terdapat beragam jenis peluang usaha pengolahan perikanan dan mereka perlu diberikan pembekalan terkait dengan peluang usaha tersebut. Kelompok sebelumnya telah berhasil membuat produk olahan makanan seperti nugget, bakso, kerupuk, pempek dan camilan. Namun, produk yang mereka hasilkan tersebut masih kurang maksimal. Perlu ada inovasi baru agar produk yang mereka hasilkan lebih baik. Disamping itu mereka sangat kesulitan dalam hal 
pemasaran. Beberapa produk tertentu mereka hasilkan, dititipkan kepada pemerintah daerah untuk diikutsertakan melalui pameran. Beberapa produk lainnya seperti kerupuk hanya dijual di warung-warung dekat rumah. Pemasaran ini tidak efektif, karena apabila tidak ada pameran maka mereka tidak berproduksi. Penjualan di warung-warung terkadang sepi pembeli. Terkait dengan permodalan kelompok sebelumnya juga tidak memiliki dukungan modal yang besar sehingga mereka kesulitan untuk mengembangkan usahanya. Ketika program pemberdayaan dari pemerintah daerah berhenti maka usaha mereka juga sulit untuk berjalan.

Prioritas permasalahan ketiga adalah ketersediaan bahan baku yang juga menjadi tantangan dalam pengembangan usaha pengolahan ikan. Pada saat musim gelombang tinggi banyak nelayan tidak melaut sehingga tidak ada hasil tangkapan ikan. Hal ini juga yang menyebabkan kelompok sebelumnya kesulitan berproduksi karena keterbatasan bahan baku. Oleh karena hal tersebut perlu ada upaya untuk mengindentifikasi musim penangkapan ikan serta rantai produksi perikanan sehingga dapat dilakukan rekayasa penyediaan bahan baku agar usaha olahan ikan kedepan dapat terus berjalan.

Teknologi pengolahan ikan yang digunakan oleh istri nelayan dalam mengolah produk perikanan meliputi penggunanan food processor yang diharapkan dapat memudahkan dalam penghancuran bahan baku, penggunaan sealer untuk pengemasan, serta penggunaan spinner untuk mengurangi kadar minyak yang dihasilkan.

Tujuan dari kegiatan Program Kemitraan Masyarakat (PKM) adalah untuk meningkatkan keberdayaan dan peningkatan kapasitas istri nelayan dalam pengolahan hasil perikanan sehingga mereka mampu meningkatkan nilai tambah produk perikanan. Kelompok tersebut diberi nama "KUB Mina Kuwaru" dan memiliki fokus dalam kegiatan pengolahan hasil perikanan. Mereka memiliki pembagian tugas kerja (struktur organisasi) kelompok yang terdiri dari ketua kelompok, bagian keuangan dan akuntansi, bagian produksi dan bagian pemasaran. Dalam proses produksinya mereka menggunakan hasil tangkapan nelayan yang kurang laku dijual untuk diolah menjadi olahan ikan yang memiliki nilai ekonomi untuk dijual. Manfaat yang diharapkan dari kegiatan ini adalah meningkatkan peran istri nelayan dalam membantu perekonomian keluarga, meningkatkan ketrampilan mereka dalam mengolah produk perikanan serta meningkatkan nilai tambah hasil perikanan. Kegiatan pengabdian serupa terkait dengan pengolahan hasil perikanan di Desa Polejiwa, Luwu Utara yaitu pembuatan kerupuk amplang Bandeng juga mampu meningkatkan ketrampilan ibu-ibu, mampu melakukan proses produksi dan pemasaran (Sari, dkk., 2019).

\section{Metode Pelaksanaan}

Tempat dan Waktu. Program Kemitraan Masyarakat (PKM) ini dilaksanakan di Dukuh Kuwaru, Desa Poncosari, Kecamatan Srandakan Kabupaten Bantul. Lokasi Kegiatan tepatnya berada di Pantai Kuwaru dan berjarak sekitar $30 \mathrm{~km}$ ke arah selatan dari pusat Kota Yogyakarta. Kegiatan ini dilaksanakan mulai dari Bulan Maret 2019 dan direncanakan berakhir pada Nopember 2019.

Khalayak Sasaran. Sasaran Program Kemitraan Masyarakat (PKM) ini adalah mitra yang mengarah kepada kegiatan ekonomi produktif. Mitra adalah kelompok istri nelayan yang berada di Dusun Kuwaru. Diantara mereka ada yang sudah berkerja tetapi banyak juga yang hanya menjadi ibu rumah tangga. Mereka yang berkerja, umumnya sebagai pedagang, petani serta membantu suami dalam jual beli hasil perikanan.

Metode Pengabdian. Pendekatan dan metode Participatory Rural Appraisal (PRA) digunakan dalam proses pemberdayaan ini. Prinsip-prinsip dalam PRA ini adalah 
1) belajar dari pengalaman masyarakat, 2) berbuat bersama, berperan setara, 3) menyeimbangkan atau mengurangi bias, 4) membuka kesadaran baru, 5) penemuan dan membangun rasa percaya diri, 5) solidaritas membangun kemitraan dan 6) memperkaya pengetahuan dan budaya lokal (Baiquni, 2001). Metode partisipatif juga dilakukan pada kegiatan peningkatan produktivitas dan kualitas dodol nangka di Desa Suranadi Lombok Barat Nusa Tenggara Barat yang memiliki orientasi kepada peran mitra dalam setiap proses dan tahapan kegiatan (Ansar dan Nazaruddin, 2018). Peneliti berdialog bersama dengan masyarakat dengan maksud untuk membuka kesadaran baru. Metode PRA ini berorientasi proses, melibatkan banyak masyarakat, terdapat upaya belajar bersama dan melibatkan berbagai kalangan masyarakat pria wanita, kaya miskin dan sebagainya. Tahapan dalam kegiatan ini adalah sebagai berikut :

1. Tahap persiapan pemberdayaan masyarakat

2. Tahapan ini dimulai dari persiapan penyiapan perizinan pemberdayaan masyarakat. Studi literatur terkait dengan proses pemberdayaan juga dilakukan pada tahap ini.

3. Tahap pendampingan pembentukan kelompok usaha pengolah hasil perikanan, penyusunan sistem administrasi, pembagian kerja dan pembukuan.

4. Kelompok usaha pengolah hasil perikanan yang akan dibentuk terdiri dari istri nelayan yang berusia produktif antara 15-55 tahun. Kelompok ini dibentuk dari, oleh dan untuk anggota kelompok. Kelompok yang dibentuk berjumlah 10 anggota. Mereka akan diarahkan untuk mengelola usaha ekonomi produktif pengolahan hasil perikanan. Tahapan selanjutnya adalah membentuk struktur organisasi kelompok dan administrasi kelembagaan.

5. FGD pemetaan potensi hasil perikanan

6. FGD dilakukan untuk menggali potensi hasil perikanan Dusun Kuwaru. FGD akan mengundang kelompok usaha pengolahan ikan yang telah dibentuk dan nelayan terkait dengan hasil perikanan Dusun Kuwaru. Hasil dari FGD ini adalah kalender musiman hasil perikanan Dusun Kuwaru.

7. Sosialisasi peluang usaha pengolahan ikan, peningkatan jiwa kewirausahaan dan perizinan usaha.

8. Pelatihan pengolahan hasil perikanan

9. Anggota kelompok harus hadir dalam kegiatan. Mereka akan mempraktikkan pembuatan olahan ikan. Pelatihan ini diharapkan dapat meningkatkan kreativitas dan inovasi bagi kelompok usaha.

10. Pelatihan Pengemasan dan Pemasaran

11. Anggota kelompok akan dilatih untuk dapat mengemas produk yang telah mereka hasilkan. Mereka akan diajarjan teknik pengemasan yang menarik bagi konsumen. Dalam pelatihan tersebut juga diajarkan teknik-teknik pemasaran dan menjalin kerjasama dengan pihak lainnya dalam pemasaran.

Indikator Keberhasilan. Indikator keberhasilan ditunjukan dari tercapainya program-program yang telah direncanakan, dengan luaran sebagai berikut :

1. Terbentuknya kelompok istri nelayan pengolah hasil perikanan. Mereka memiliki struktur organisasi dan pembukuan

2. Tersusunya kalender musim penangkapan ikan Pantai Kuwaru

3. Peningkatan jiwa kewirausahaan dan pemahaman terkait dengan perizinan

4. Peningkatan kemampuan dan ketrampilan dalam pengolahan hasil perikanan ditunjukkan dengan terwujudnya produk amplang ikan dan krispi ikan.

5. Mitra mampu mengemas produk yang dihasilkan menjadi lebih menarik dan memiliki nilai tambah untuk dijual

6. Peningkatan pendapatan kelompok.

Metode Evaluasi. Evaluasi terhadap kegiatan yang telah dilaksanakan menggunakan prinsip yaitu 1) peningkatan, 2) kepemilikan komunitas, 3) inklusi, 
4) partisipasi yang demokratis, 5) keadilan sosial, 6) pengetahuan komunitas, 7) strategi berbasis bukti, 8) pembangunan kapasitas, 9) pembelajaran organisasi dan 10) akuntabilitas (Fetterman, 2005). Evaluasi ini menjadi sangat penting karena memberikan penilaian terhadap program dan kegiatan yang dijalankan apakah mempengaruhi kehidupan mereka atau tidak. Tahapan evaluasi yang dilakukan meliputi dua tahapan yaitu tahapan pada saat pelaksanaan kegiatan dan tahapan setelah kegiatan berakhir. Tahapan evaluasi yang pertama apabila kegiatan berjalan sesuai dengan rencana kegiatan yang dilaksanaan. Evaluasi kegiatan tahap kedua dilihat dari peningkatan ketrampilan dan juga peningkatan pendapatan kelompok istri nelayan setelah kegiatan telah berakhir.

\section{Hasil dan Pembahasan}

\section{A. Pembentukan Kelompok Usaha Pengolahan Hasil Perikanan}

Kelompok istri nelayan yang dibentuk beranggotakan sepuluh (10) anggota. Jumlah anggota yang tidak terlalu banyak diharapkan dapat meningkatkan efisiensi kelompok. Apabila menengok pada kelompok yang sudah ada sebelumnya, jumlah anggota yang terlalu banyak menjadikannya tidak efektif dan menjadi tidak fokus terhadap tugas dalam organisasi. Mereka bergabung dalam kelompok secara sukarela dan tanpa ada paksaan dari pihak manapun. Kelompok ini diberi nama kelompok "Mina Kuwaru" sejalan dengan rencana kelompok yang fokus dalam pengolahan hasil perikanan. Pembentukan kelompok diikuti dengan pembentukan struktur organisasi kelompok yang terdiri dari ketua kelompok, bagian keuangan dan akuntasi, bagian produksi dan bagian pemasaran. Proses pembentukan kelompok ini didampingi oleh tim dan narasumber yang ahli dibidangnya. Pemilihan anggota untuk masing-masing bagian berdasarkan pada musyawarah bersama serta kemampuan dan keahlian masing-masing anggota.

Dalam pembentukan kelompok tersebut, disampaikan materi terkait dengan kelembagaan dan pembukuan oleh tim dan narasumber. Materi terkait dengan organisasi kerja disampaikan oleh tim. Dalam paparannya disampaikan terdapat pola organisasi kerja pada usaha mikro dengan tiga fungsi utama yaitu produksi, pemasaran dan penjualan serta keuangan dan akuntansi. Pembentukan kelompok istri nelayan disajikan dalam Gambar 1.

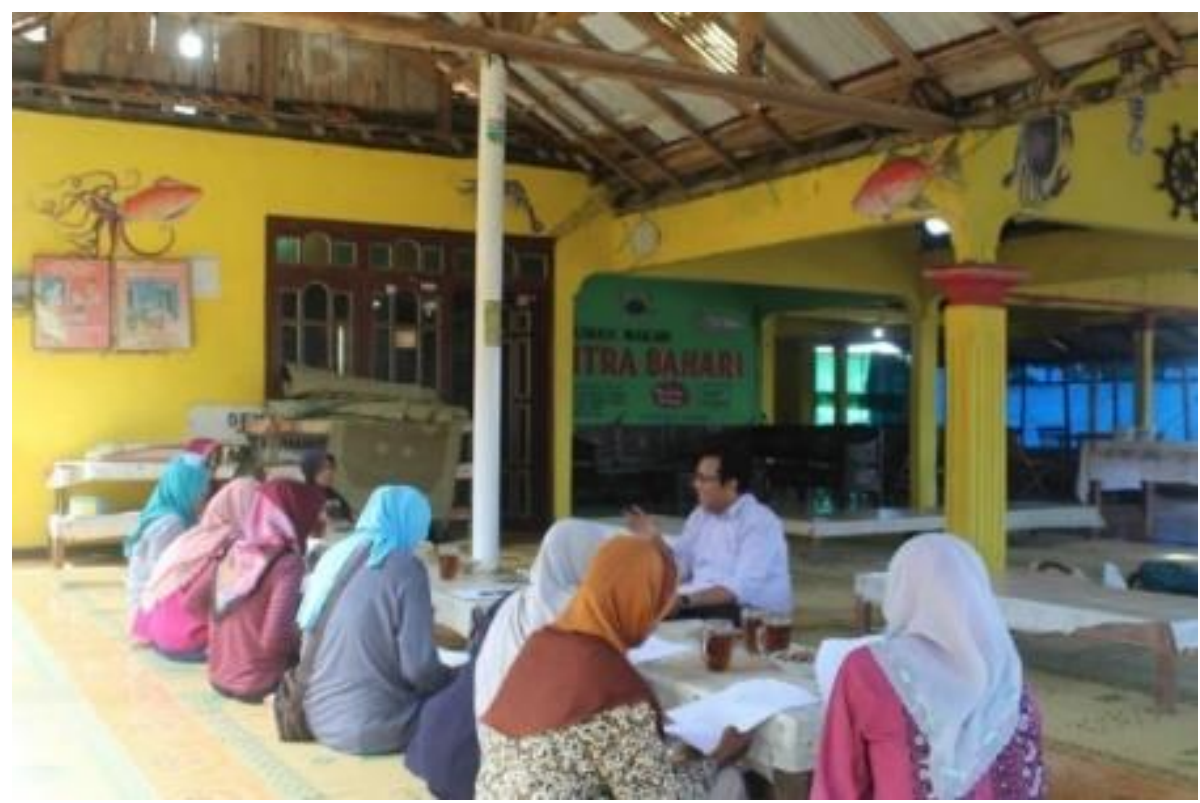

Gambar 1. Musyawarah pembentukan kelompok istri nelayan (Sumber: data primer, 2019) 


\section{B. FGD Pemetaan Potensi Hasil Perikanan}

FGD bersama dengan kelompok nelayan dan kelompok istri nelayan terkait dengan potensi hasil perikanan dimaksudkan untuk melakukan identifikasi terhadap hasil-hasil ikan yang ditangkap nelayan kuwaru serta melakukan identifikasi terhadap ikan yang kurang laku dipasaran(Gambar 2). Pemetaan potensi hasil perikanan ini telah di presentasikan dalam Seminar Nasional Geografi UMS ke-10 dengan judul paper yaitu "Pendekatan Partisipatif dalam Pemetaan Potensi Hasil Perikanan di Dukuh Kuwaru, Poncosari, Srandakan, Bantul" (Setyaningrum, dkk., 2019). Dalam paper yang dipresentasikan tersebut disebutkan bahwa pada saat musim melaut nelayan mendapatkan banyak ikan namun tidak semua ikan yang ditangkap laku untuk dijual dipasaran. Beberapa ikan yang kurang laku dijual yaitu Ikan Terubuk, Ikan Lendra dan Ikan Tombol (Setyaningrum dkk., 2019). Ikan-ikan jenis ini terkadang dimanfaatkan untuk pakan lele, ikan asin atau bahkan dibuang oleh nelayan. Kalender musim hasil perikanan disajikan dalam Gambar 3.

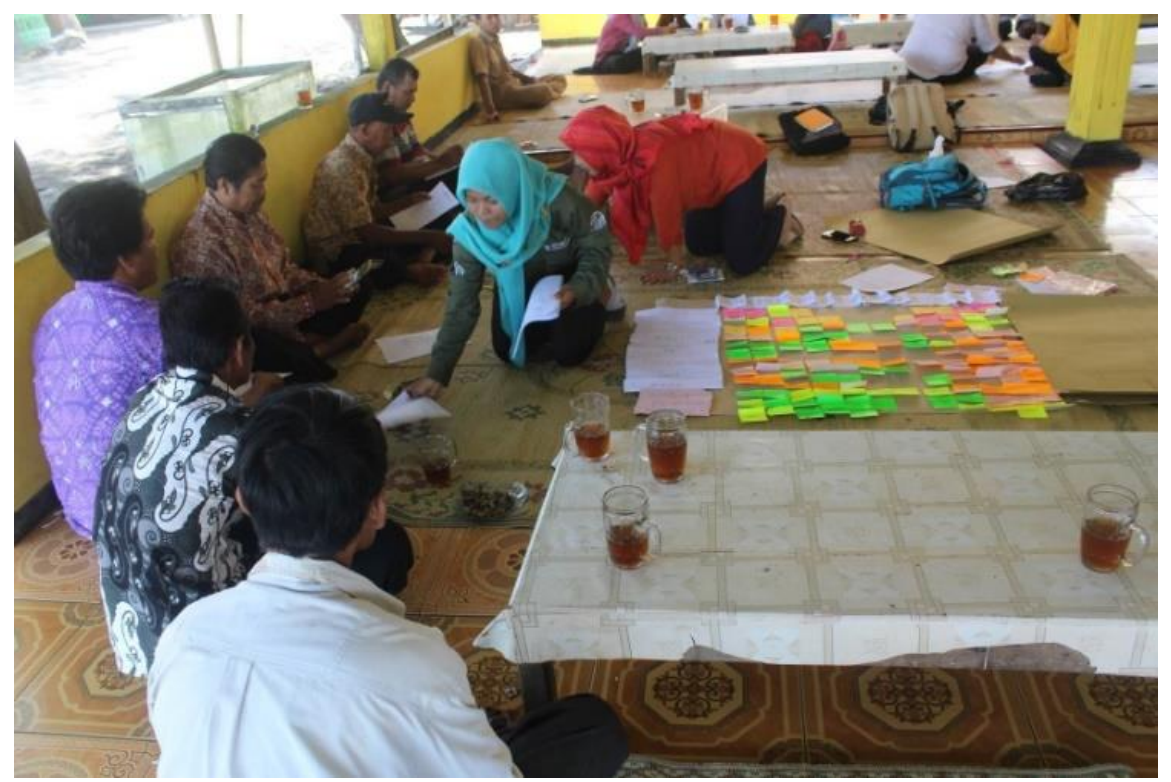

Gambar 2. FGD Pemetaan hasil perikanan (Sumber: data primer, 2019)

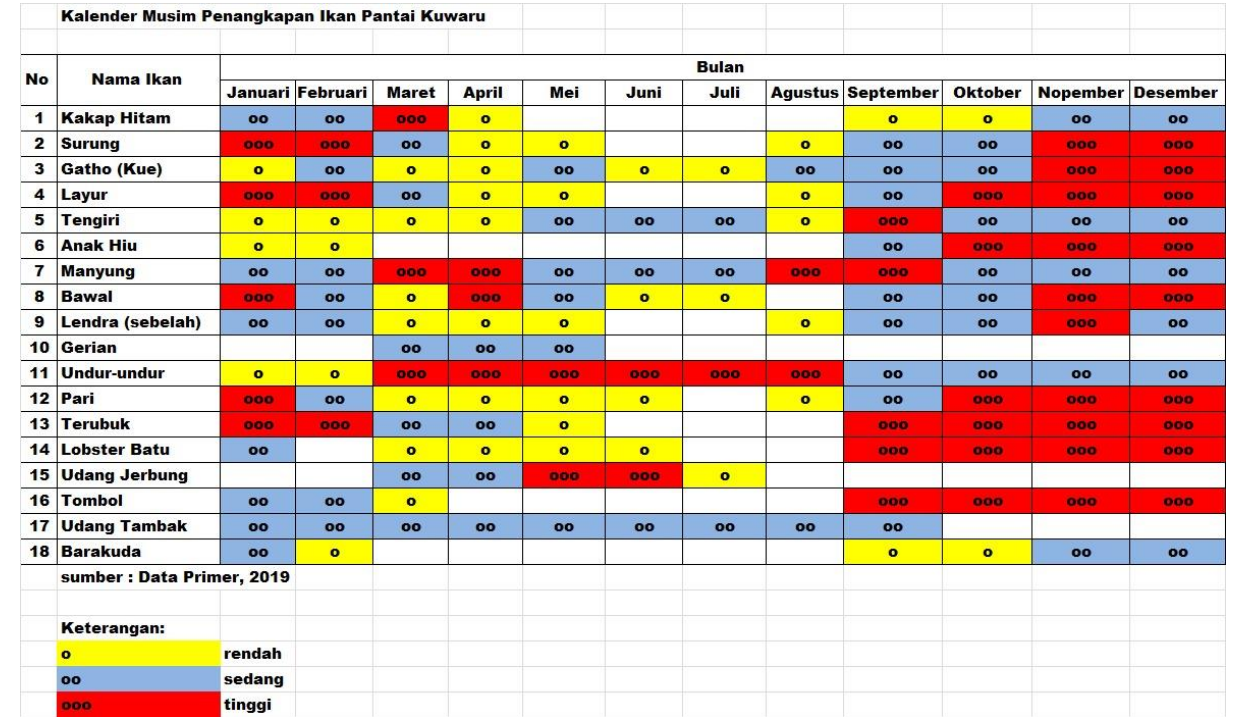

Gambar 3. Kalender musim potensi hasil perikanan kuwaru (Sumber:

Setyaningrum, Hartanto and Nugroho, 2019) 


\section{Sosialisasi Peningkatan Jiwa Kewirausahaan dan Perizinan Usaha}

Peningkatan jiwa kewirausahaan menjadi salah satu modal yang penting yang harus dimiliki calon wirausaha untuk membangun dan mengembangkan usahanya. Beberapa anggota kelompok merupakan pedagang warung dan rumah makan yang membuka usahanya di Pantai Kuwaru. Meskipun demikian, peningkaan jiwa kewirausahaan harus diaasah dan ditingkatkan seiring dengan dinamika dan perkembangan zaman. Narasumber yang dihadirkan dalam sosialisasi adalah seorang narasumber yang memiliki kompetensi dibidang wirausaha serta memiliki usaha. Salah satu materi yang disampaikan dalam sosialisasi ini terkait dengan tips menjadi wirausaha yang terdiri dari niat, memiliki impian, menerapkan apa yang diimpikan dan beraksi. Dalam sosialisasi tersebut disampaikan terkait pentingnya wirausaha yang menjadi salah satu sarana untuk meningkatkan perekonomian bangsa dan meningkatkan kesejahteraan masyarakat. Kondisi pada saat sosialisasi jiwa wirausaha disajikan dalam Gambar 4.

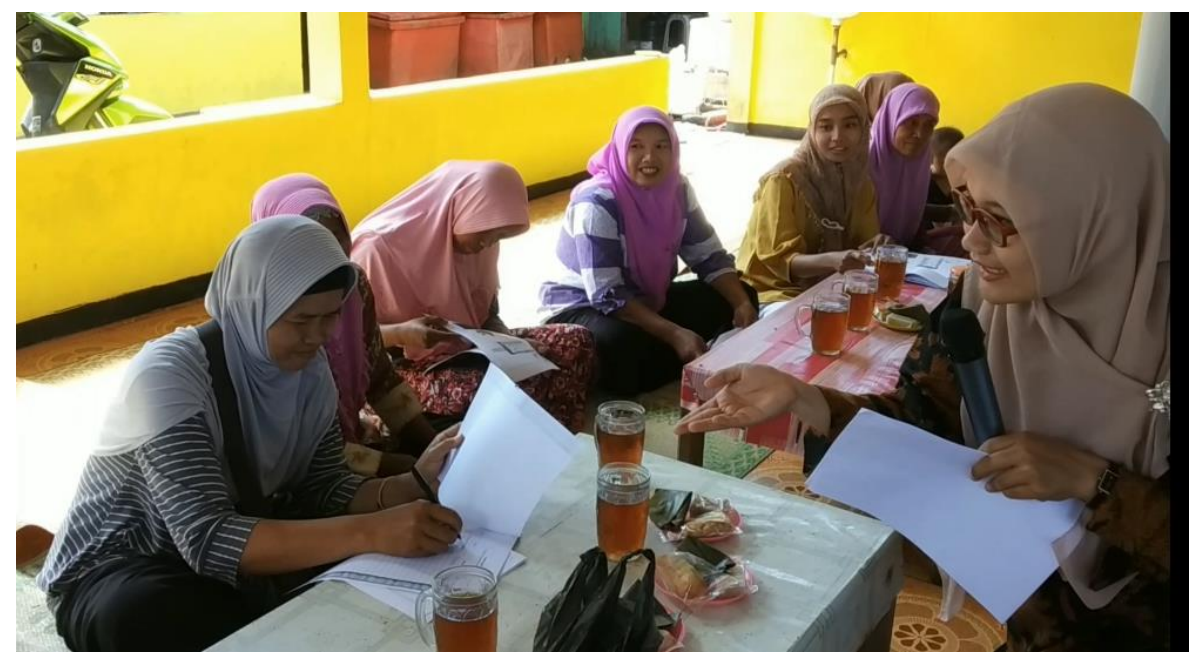

Gambar 4. Sosialisasi kewirausahaan dan perizinan usaha (Sumber: data primer, 2019)

\section{Pelatihan Pengolahan Ikan}

Pelatihan pengolahan ikan menggunakan ikan yang kurang laku dijual. Beberapa hasil pengolahan ikan yang dihasilkan oleh kelompok antara lain amplang, krispi udang dan krispi ikan (Gambar 5). Apabila melihat pada kelompok sebelumnya yang pernah menghasilkan olahan ikan seperti naget, bakso dan lainnya maka pelatihan pengolahan ikan menyasar suatu produk yang belum pernah dibuat dan diharapkan menjadi produk unggulan baru. Produk yang diharapkan adalah suatu produk yang mudah untuk dibuat dan diaplikasikan. Produk amplang/kuku macan, menjadi salah satu produk yang dipilih untuk diolah. Pelatihan pengolahan ikan dihadiri oleh seluruh anggota kelompok. Hasil pelatihan tersebut menujukkan tingkat kesulitan yang dihadapi kelompok dalam pembuatannya. Beberapa anggota yang membuat kerupuk amplang sesuai dengan takarannya mengalami keberhasilan, sedangkan yang lainnya gagal.

\section{Pelatihan Pengemasan dan Pemasaran}

Dewasa ini pengemasan menjadi hal yang sangat penting dan harus diperhatikan dalam sebuh proses produksi. Kemasan tidak hanya berfungsi untuk menyimpan dan melindungi produk, namun kemasan sekarang ini menjadi salah satu sarana pemasaran yang penting (Purnavita, dkk., 2018). Produk akan menjadi lebih menarik dan memiliki nilai tambah. Inovasi dan penggunaan teknologi pengemasan harus dilakukan agar produk yang dihasilkan menjadi lebih menarik, lebih tahan lama dan meningkatkan nilai jualnya. 


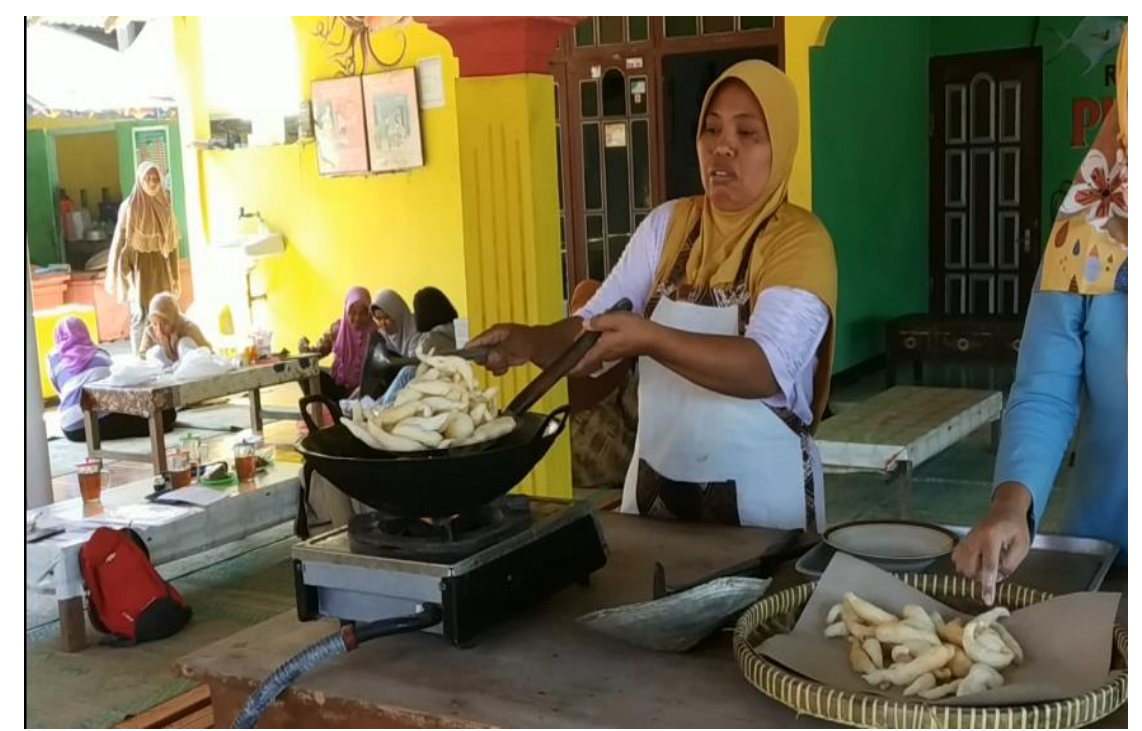

Gambar 5. Pelatihan pembuatan kerupuk amplang/kuku macan

(Sumber: data primer, 2019)

Pelatihan pengemasan dilakukan bersama dengan narasumber yang ahli dibidangnya. Narasumber berasal dari Pusat Kemasasan UKM Jogja. Materi yang disampaikan terkait dengan ketentuan yang harus ada dalam sebuah kemasan yaitu 1) merk produk, 2) yang memproduksi sebuah produk, 3) komposisi produk, 4) berat bersih produk, 5) tanggal kadaluarsa, 6) kode produksi, 7) legalitas usaha (PIRT, Halal dan Perizinan usaha). Anggota kelompok juga dilatih untuk mengemas produk yang telah dihasilkan menggunakan berbagai macam kemasan (Gambar 6). Dalam proses pengemasan pemasangan stiker, proses sealing dan pembuatan desain kemasan menjadi satu tantangan tersendiri bagi kelompok. Dalam pelatihan tersebut mereka diajarkan bagaimana proses untuk memasang stiker yang benar pada sebuah kemasan, tips dan trik membuat desain kemasan yang menarik dan manjual serta melalukan proses sealing saat pengemasan. Dalam pelatihan tersebut mereka mampu membuat kemasan produk lebih menarik dan memiliki nilai tambah. Sebelumnya mereka juga mengemas produk namun belum memiliki label (Gambar 7). Produk yang dihasilkan setelah pelatihan pengemasan disajikan dalam Gambar 8. Materi lainnya terkait dengan pemasaran. Mereka diarahkan untuk mampu memasarkan suatu produk secara online mengingat perkembangan teknologi yang sangat pesat. Salah satu anggota yang masih muda diarahkan untuk mampu memasarkan produk secara online.

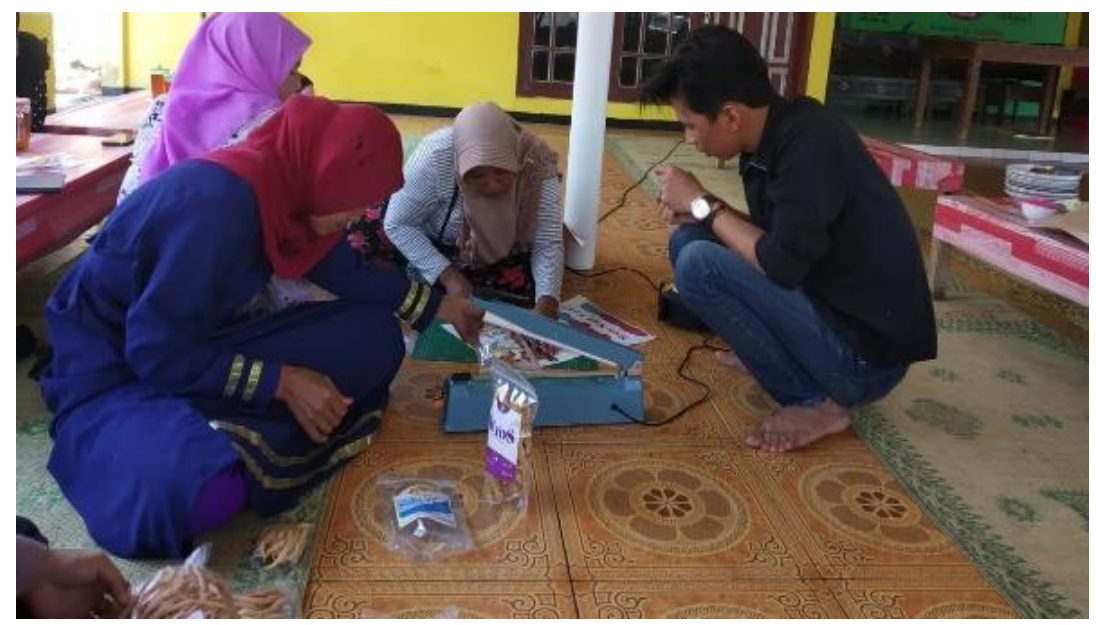

Gambar 6. Pelatihan pengemasan (sumber: data primer, 2019) 


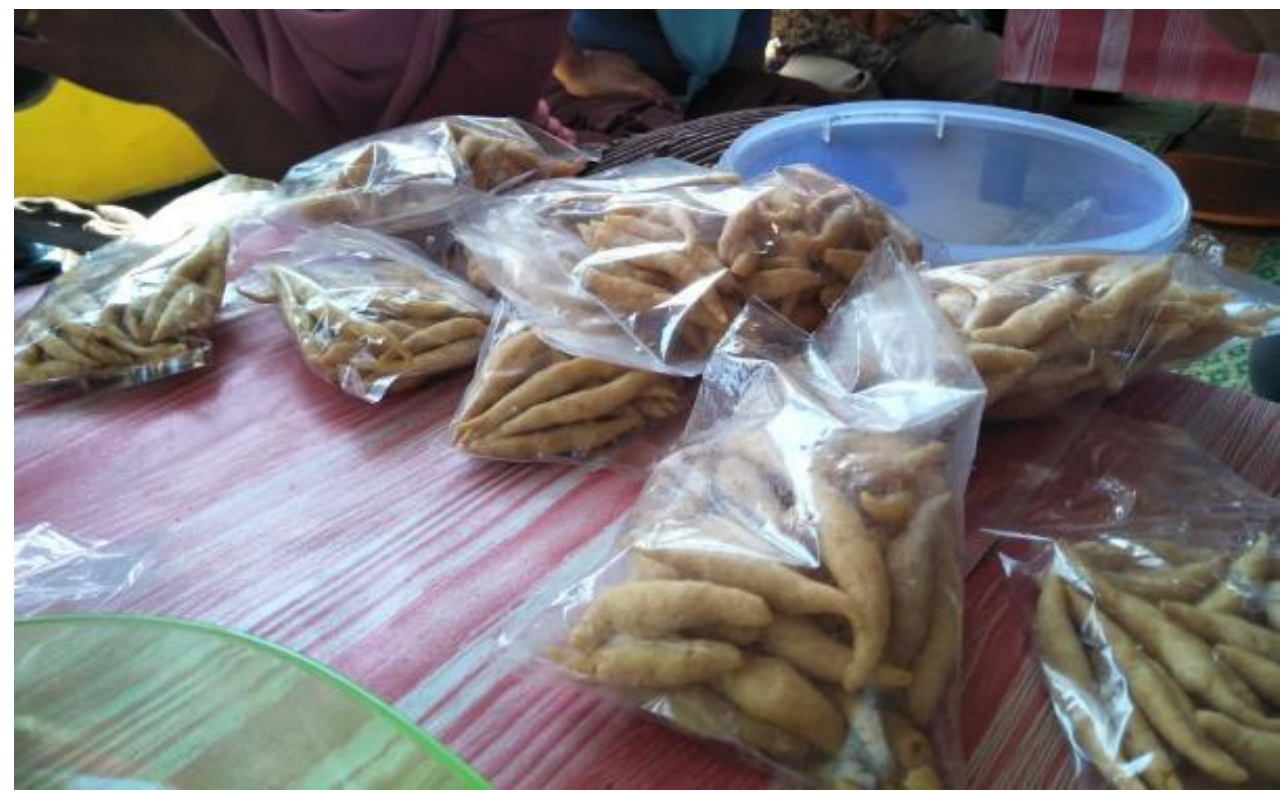

Gambar 7. Produk yang belum memiliki label (Sumber: data primer, 2019)

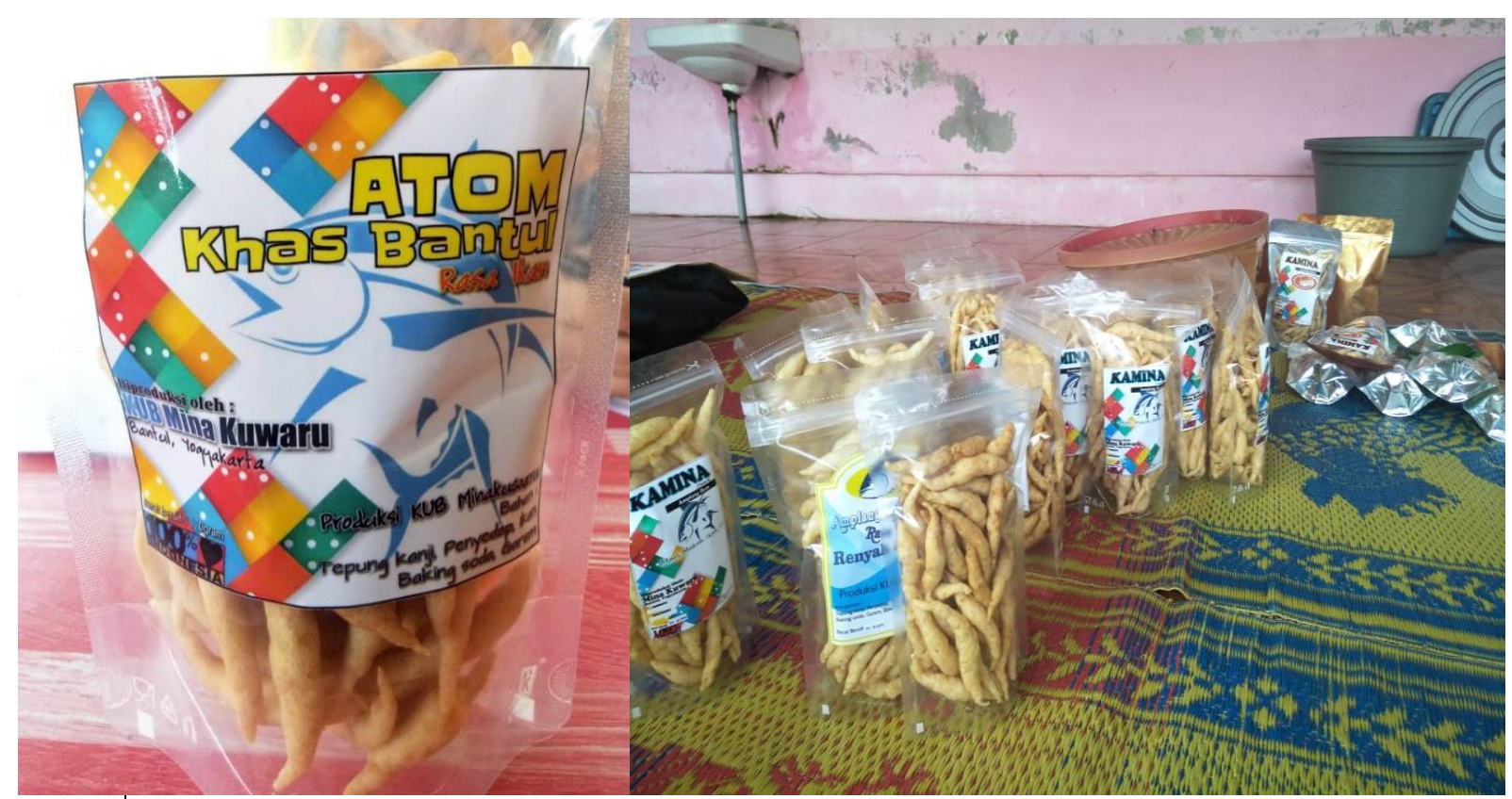

Gambar 8 Produk yang dihasilkan setelah pelatihan pengemasan (Sumber: data primer, 2019)

\section{E. Keberhasilan Kegiatan}

Evaluasi terkait dengan keberhasilan kegiatan dapat dilihat dari meningkatkan ketrampilan kelompok istri nelayan dengan ditunjukkan dari kemampuan mereka membuat kerupuk amplang ikan, mampu mengemas dan memasarkan produk yang telah dihasilkan. Produk yang dihasilkan tidak hanya amplang tetapi juga krispi ikan, krupuk udang dan frozen food yaitu bakso ikan, empek-empek, dan cireng. Pemasaran dilakukan di Pantai Kuwaru, Pantai Baru, Pantai Goa Cemara dan beberapa mini market disekitar Dusun Kuwaru. Berikut disajikan keuntungan bersih yang didapatkan oleh kelompok pada Gambar 9. Keuntungan yang diperoleh tidak hanya karena penjualan lokal tetapi mereka juga mengikuti pameran. 


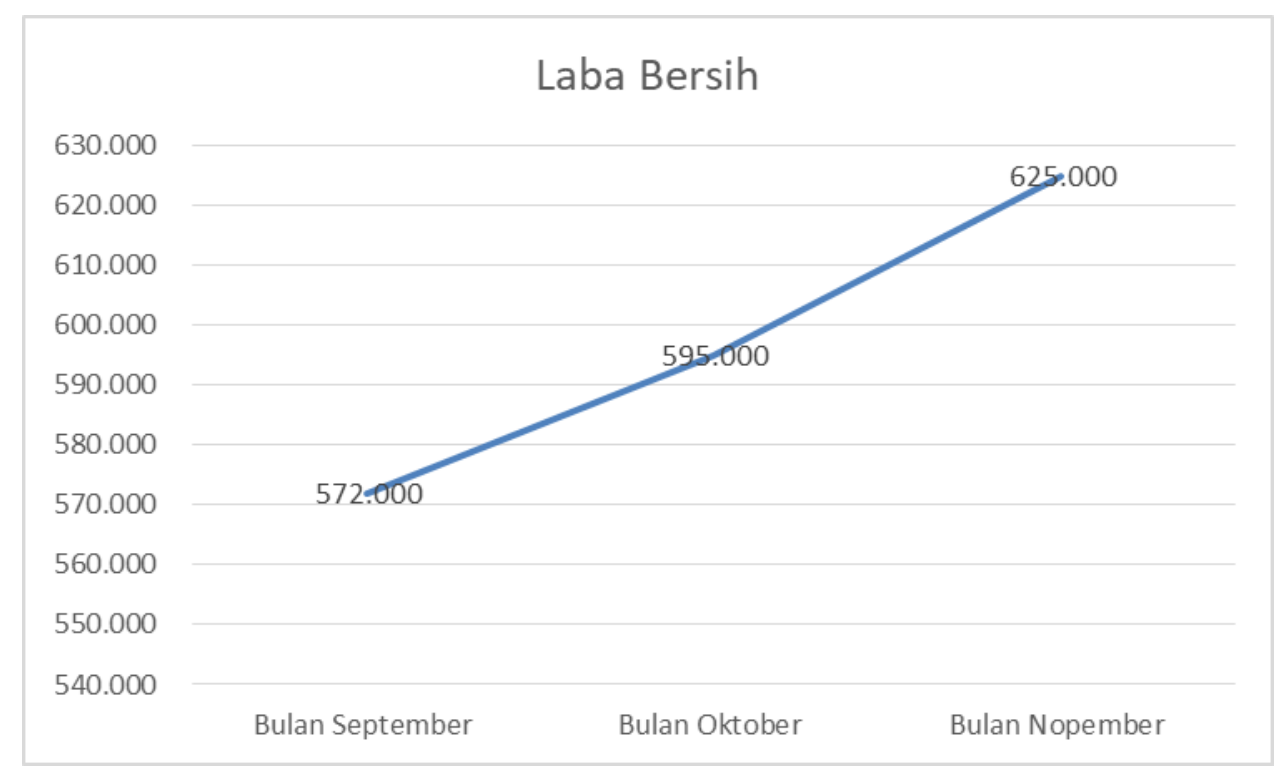

Gambar 9. Laba bersih penjualan olahan ikan (Sumber: Data Primer, 2019)

\section{Kesimpulan}

Program ini mampu meningkatkan keberdayaan dan peningkatan kapasitas istri nelayan yang ditunjukkan melalui terbentuknya kelompok istri nelayan pengolah hasil perikanan, kemampuan dalam mengolah hasil perikanan menjadi produk olahan ikan antara lain kerupuk amplang dan krispi ikan. Mereka juga telah mampu menghasilkan sebuah produk yang telah dikemas dan dipasarkan. Meskipun demikian kelompok ini harus terus didampingi hingga menjadi kelompok yang mandiri dan berkelanjutan.

\section{Ucapan Terima Kasih}

Penulis mengucapkan terima kasih kepada DRPM Kemenristekdikti, Mitra yang merupakan kelompok istri Nelayan Dukuh Kuuwaru, Masyarakat Dukuh Kuwaru, Pemerintah Desa Poncosari, Mahasiswa Teknik Kelautan dan Teknik Lingkungan ITY, LP2M ITY, Bapak dan Ibu Dosen Teknik Kelautan serta beberapa pihak lainnya yang telah membantu pelaksanaan PKM.

\section{Referensi}

Ansar \& Nazaruddin. (2018). Peningkatan Produktivitas dan Kualitas Dodol Nangka di Desa Suranadi Lombok Barat Nusa Tenggara Barat. Jurnal Panrita Abdi, 2(2), pp. 135-141. Available at: http://journal.unhas.ac.id/index.php/ panritaabdi/article/view/5117/2805 .

Baiquni, M. (2001). Makalah disampaikan pada National Training Session Cohort IX LEAD Leadership For Environment and Development YPB Yayasan Pembangunan Berkelanjutan.

Fetterman, D.M. (2005). Empowerment Evaluation Principles in Practice, Guilford Publications. Available at: https://www.guilford.com/excerpts/fetterman. pdf?t.

Kurniawati, A. (2017). Peran Istri Nelayan Dalam Rangka Meningkatkan Pendapatan Keluarga. Jurnal Sains Dan Teknologi Maritim, XVII(September), pp. 77-88. Available at: http://jurnal.stimart-amni.ac.id/index.php/JSTM/ article/view/ 160.

Purnavita, S., Sriyana, H.Y. \& Widiastuti, T. (2018). Kemasan Menarik dan Internet Marketing untuk Meningkatkan Nilai Jual Emping Garut sebagai Produk 
Unggulan Kabupaten Sragen. E-DIMAS: Jurnal Pengabdian kepada Masyarakat, 9(1), pp. 88-97. doi: 10.26877/e-dimas.v9i1.2260.

Sari, H. \& Hafid, A. (2019). Pengembangan Usaha Kerupuk Amplang Bandeng untuk Memberdayakan Masyarakat Desa Polejiwa Kecamatan Malangke Barat Kabupaten Luwu Utara Provinsi Sulawesi Selatan. Jurnal Panrita Abdi, 3(2), pp. 161-169. Available at: http://journal.unhas.ac.id/index.php/panritaabdi/ article/view/5624/4240.

Setyaningrum, A., Hartanto, B. \& Nugroho, A.S. (2019). Pendekatan Partisipatif Dalam Pemetaan Potensi Hasil Perikanan Di Dukuh Kuwaru, Poncosari, Srandakan, Kabupaten Bantul, dipunlikasikan dalam Seminar Nasional UMS $\mathrm{Ke}-10$.

Sumrin, Olii, A.H. \& Baruadi, A.S.R. (2015). Studi Peran Perempuan Pesisir dalam Menunjang Aktivitas Perikanan di Desa Torosiaje Laut Kecamatan Popayato Kabupaten Pohuwato. Jurnal Ilmiah Perikanan dan Kelautan, 3(1), pp. 16-19.

Penulis:

Agustina Setyaningrum, Prodi Teknik Kelautan, Fakultas Teknologi Sumber Daya Alam, Institut Teknologi Yogyakarta. E-mail: agustina678@ity.ac.id

Broto Widya Hartanto, Prodi Teknik Industri, Fakultas Teknologi Industri, Institut Teknologi Yogyakarta. E-mail: brotohartanto@gmail.com

Bagaimana men-sitasi artikel ini:

Setyaningrum, A., \& Hartanto, B.W. (2020). Peningkatan Kapasitas Istri Nelayan dalam Pengolahan Hasil Perikanan di Dusun Kuwaru Desa Poncosari Kabupaten Bantul. Jurnal Panrita Abdi, 4(2), 184 194. 